\title{
Diversity and pathogenicity of the Ceratocystidaceae associated with cacao agroforests in Cameroon
}

M. Mbenoun a, M. J. Wingfielda, A. D. Begoude Boyogueno ${ }^{\mathrm{a}, \mathrm{c}}$, F. Nsouga Amougou ${ }^{\mathrm{c}}$, S.

Petchayo Tigang ${ }^{\mathrm{c}}$, G. M. ten Hoopen ${ }^{\mathrm{c}, \mathrm{d}}$, C. V. Mfegue ${ }^{\mathrm{c}}$, L. Dibog ${ }^{\mathrm{c}}$, S. Nyassé ${ }^{\mathrm{c}}$, B. D. Wingfield ${ }^{\mathrm{b}}$, J. Roux ${ }^{a^{*}}$

${ }^{a}$ Department of Microbiology and Plant Pathology, Forestry and Agricultural Biotechnology Institute (FABI), University of Pretoria, Private bag X20, Pretoria 0028, South Africa

${ }^{\mathrm{b}}$ Department of Genetics, Forestry and Agricultural Biotechnology Institute (FABI), University of Pretoria, Private bag X20, Pretoria 0028, South Africa

${ }^{\mathrm{c}}$ Institut de Recherche Agricole pour le Développement (IRAD), B.P. 2067 Yaounde, Cameroon

${ }^{\mathrm{d}}$ Centre de Coopération Internationale en Recherche Agronomique pour le Développement (CIRAD), UR106

Bioagresseurs: analyse et maîtrise de risque, B.P. 2572 Yaounde, Cameroon

*E-mail: jolanda.roux@fabi.up.ac.za

\begin{abstract}
Knowledge of the diversity and ecology of plant pathogenic fungi in cacao agroforests and surrounding natural ecosystems can inform the development of sustainable management strategies for new cacao disease outbreaks. In this study, we investigated the occurrence of fungi related to the Ceratocystisdaceae and their nitidulid beetle vectors in cacao agroforests in Cameroon, under diverse agroecological conditions. The fungi and their vectors were collected
\end{abstract}


from artificially induced stem wounds on cacao and associated shade trees. Collections were also made from abandoned cacao pod husks and other tree wounds within and around plantations. Fungal isolates were identified using DNA sequence-based phylogenies and morphological comparisons, and two representatives of each species were evaluated for pathogenicity on cacao. Five species of Ceratocystidaceae were recovered, including Huntiella chlamydoformis sp. nov., H. pycnanthi sp. nov. and H. moniliformis, as well as Thielaviopsis cerberus and Th. ethacetica. The incidence of these fungi appeared to be influenced by the prevailing agroecological conditions. Nitidulid beetles in the genus Brachypeplus were found to be their most common insect associates on cacao. Both Th. ethacetica and H. pycnanthi produced extensive lesions after inoculation on branches of mature cacao trees, while Th. ethacetica also caused pod rot. Although their impact remains unknown, fungi in the Ceratocystidaceae and their nitidulid beetle vectors are common and likely contribute to the parasitic pressure in Cameroonian cacao agrosystems.

Keywords: Crop protection, Ceratocystis, emerging diseases, fungal pathogens, Nitidulid beetles

\section{Introduction}

Cacao (Theobroma cacao L.) is affected by numerous pests and pathogens, and these represent the primary production constraint for this crop (Gotsch, 1997; Bowers et al., 2001). In this regard, fungal pathogens have emerged as a serious threat to the sustainability of the global cacao industry (Bowers et al., 2001; Ploetz, 2007), being responsible for losses estimated at 30 to $40 \%$ of potential annual world cocoa (cacao beans) production (http://www.icco.org/about-cocoa/pesta-diseases.html). Cocoa yield losses due to fungal pathogens are also expected to increase 
substantially in the future. This is because the most destructive fungal diseases of cacao, including black pod disease (BPD) caused by various species of Phytophthora, and especially $P$. megakarya Brasier \& M.J. Griffin, in Africa; frosty pod rot caused by Moniliophthora roreri H.C. Evans, Stalpers, Samson \& Benny as well as witches' broom caused by M. perniciosa (Stahel) Aime \& Phillips-Mora in Latin America, are spreading to new areas (Evans, 2007). Cameroon produces approximately 220000 metric tons of cocoa per annum and is ranked fifth amongst the major world cocoa producers (www.worldcocoa.org). In Cameroon, cacao is generally cultivated by smallholder farmers in complex and diversified agroforestry systems, commonly intermingling cacao with fruit trees and other agricultural crops in thinned primary forests (Mbile et al., 2009). These production systems add ecological and economic value (Rice \& Greenberg, 2000; Mbile et al., 2009), but they also provide suitable conditions for outbreaks of various pests and diseases (Schroth et al., 2000).

The occurrence and impact of pests and pathogens of cacao has consistently increased in Cameroon since the crop was first introduced into the country in the late 1800's. In addition to severe mirid (Heteroptera: Miridae) damage recorded from the very early years of cacao cultivation, there has been a dramatic increase in yield losses due to $\mathrm{BPD}$, resulting from the emergence of P. megakarya (native in Cameroon) in the 1970's (Sonwa et al., 2005; Mfegue, 2012) and, more recently, an upsurge in tree mortality associated with infections by Lasiodiplodia theobromae (Pat.) Criffon \& Maubl. (Mbenoun et al., 2008). While it might not be possible to predict the nature of a next disease outbreak on cacao in Cameroon, the two cases mentioned above highlight the need for a better knowledge of the diversity of plant pathogenic fungi found naturally in surrounding ecosystems. This is also supported by changing 
environmental conditions and associated abiotic stress, which could increase cacao vulnerability to attacks by secondary or latent pathogens (Garett et al., 2006).

This study study considered fungi belonging to the recently revised ascomycete family Ceratocystidaceae (de Beer et al., 2014). This diverse and widely distributed group of fungi (Wingfield et al., 1993; Seifert et al., 2013; de Beer et al., 2014) includes numerous plant pathogens associated with fruit and tuber rot, canker and wilt diseases (Kile, 1993; Roux \& Wingfield, 2009). These pathogens infect their hosts through wounds and are most commonly transmitted by insects, including nitidulid (Coleoptera: Nitidulidae) beetles (e.g., Moller and Devay, 1968b; Hayslett et al., 2008; Heath et al., 2009). A number of species of Ceratocystidaceae have been reported to affect cacao, the best known of which is Ceratocystis cacaofunesta C. J. B. Engelbr. \& T. C. Harr., a wilt pathogen that has been associated with substantial tree mortality in Central and South American cacao orchards (Engelbrecht et al., 2007). There is also growing evidence to suggest that diseases of tree crops caused by fungi in the Ceratocystidaceae and especially Ceratocystis species are increasing worldwide (e.g. Al Adawi et al., 2006; Roux \& Wingfield, 2009; Wingfield et al., 2013), justifying greater attention being paid to the diversity of these fungi globally.

Despite their obvious importance, the incidence and impact of the Ceratocystidaceae in Africa, especially Central and West Africa encompassing the cacao growing regions, is largely unknown. The aims of this study in cacao agroforests of Cameroon were thus to (i) determine the occurrence of these fungi and their nitidulid vectors; (ii) characterize their species diversity; and (iv) assess their pathogenicity on cacao. 


\section{Materials and methods}

\section{Study sites}

Field studies were undertaken during the cacao harvesting seasons, between October and November 2009 and 2010, at three sites in the Centre-South cacao growing basin of Cameroon (Supplementary Material - Figure S1). This region is characterized by a tropical rainforest vegetation type, extending slightly into moist savanna grassland to the north. The climate is subequatorial, with an average temperature of $27^{\circ} \mathrm{C}$ and annual rainfall ranging from 1300 to $2000 \mathrm{~mm}$ and distributed over a bimodal seasonal pattern.

Four cacao stands were selected for the study and these were based on differences in age, ecological conditions and the cacao farming system being applied. One stand $\left(4^{\circ} 30^{\prime} 16.7^{\prime \prime} \mathrm{N}\right.$, $\left.11^{\circ} 4^{\prime} 44.9^{\prime \prime} \mathrm{E}\right)$ was located in Bokito, a relatively dry forest-savanna transition zone at the northwest limit of the region. The farm was established in the early 1990's on savanna and included various agricultural and food crops such as oil palm, banana and pineapple, within or alongside the cacao plot. It was slightly shaded by a few non-native fruit trees and indigenous Ceiba pentandra (L.) Gaertn. Two stands $\left(3^{\circ} 16^{\prime} 6.4^{\prime \prime} \mathrm{N}, 11^{\circ} 14^{\prime} 29.9^{\prime \prime} \mathrm{E}\right.$ and $\left.3^{\circ} 16^{\prime} 3.5^{\prime \prime} \mathrm{N}, 11^{\circ} 14^{\prime} 50.4^{\prime \prime} \mathrm{E}\right)$ were located in Ngomedzap, in the humid forest zone. Both plantations were over 60-years-old, but with variable cacao tree ages. They were established in thinned primary forest with a high density and diversity of remnant forest shade trees dominated by Terminalia superba Engl. \& Diels. Some banana and fruit trees were also present in these stands. The fourth stand $\left(2^{\circ} 49^{\prime} 10.5^{\prime \prime} \mathrm{N}, 11^{\circ} 7^{\prime} 57.9^{\prime \prime} \mathrm{E}\right)$ was also located in the humid forest zone, at the Nkoemvone research station of the Institute of Agricultural Research for Development (IRAD), where several cacao genotype plots are maintained. The plots included in this study were being rejuvenated. 
They were planted in the 1970's on land completely cleared of primary forest, using scattered, non-native Cassia spectabilis (DC.) Irwin \& Barn. as shade trees.

\section{Collections}

Ten cacao trees (diameter at breast height $\geq 20 \mathrm{~cm}$ ), at least $50 \mathrm{~m}$ apart, and three to five dominant shade trees (Ceiba pentandra at Bokito, Terminalia superba at Ngomedzap and Cassia spectabilis at Nkoemvone) were selected at each site and marked. Wounds (one on cacao and two on shade trees) were made on the stems of the trees following the technique described by Barnes et al. (2003). Wounds were established $\sim 1.5 \mathrm{~m}$ above ground. Approximately $10 \times 10 \mathrm{~cm}$ of bark was cut from the stems using masonry chisels to expose the cambium and a $\sim 5 \times 5 \mathrm{~mm}$ slit was

made into the sapwood at the centre of the cleared cambium to expose the vascular tissue (Figure 1a). At Nkoemvone, induced wounds were modified by lifting the bark at the top and bottom to create niches for visiting nitidulid beetles.

Artificially induced wounds were inspected after two weeks. Where nitidulid beetles had infested the wounds, the insects were collected using an aspirator and maintained in glass vials. Wound surfaces were examined using a 10× magnification hand lens to determine the presence of fungal fruiting structures. The presence of internal discoloration in the sapwood was also determined by removing the surface wood and edges of wounds. Slices of wood and bark carrying fungal structures, or with discoloration, were collected in paper bags and transported to the laboratory for further study. After removing all visibly discoloured wood from the trees, wounds were treated with copper oxide (Nordox, Norway) and covered with "artificial bark" (Lac Balsam, Germany). 

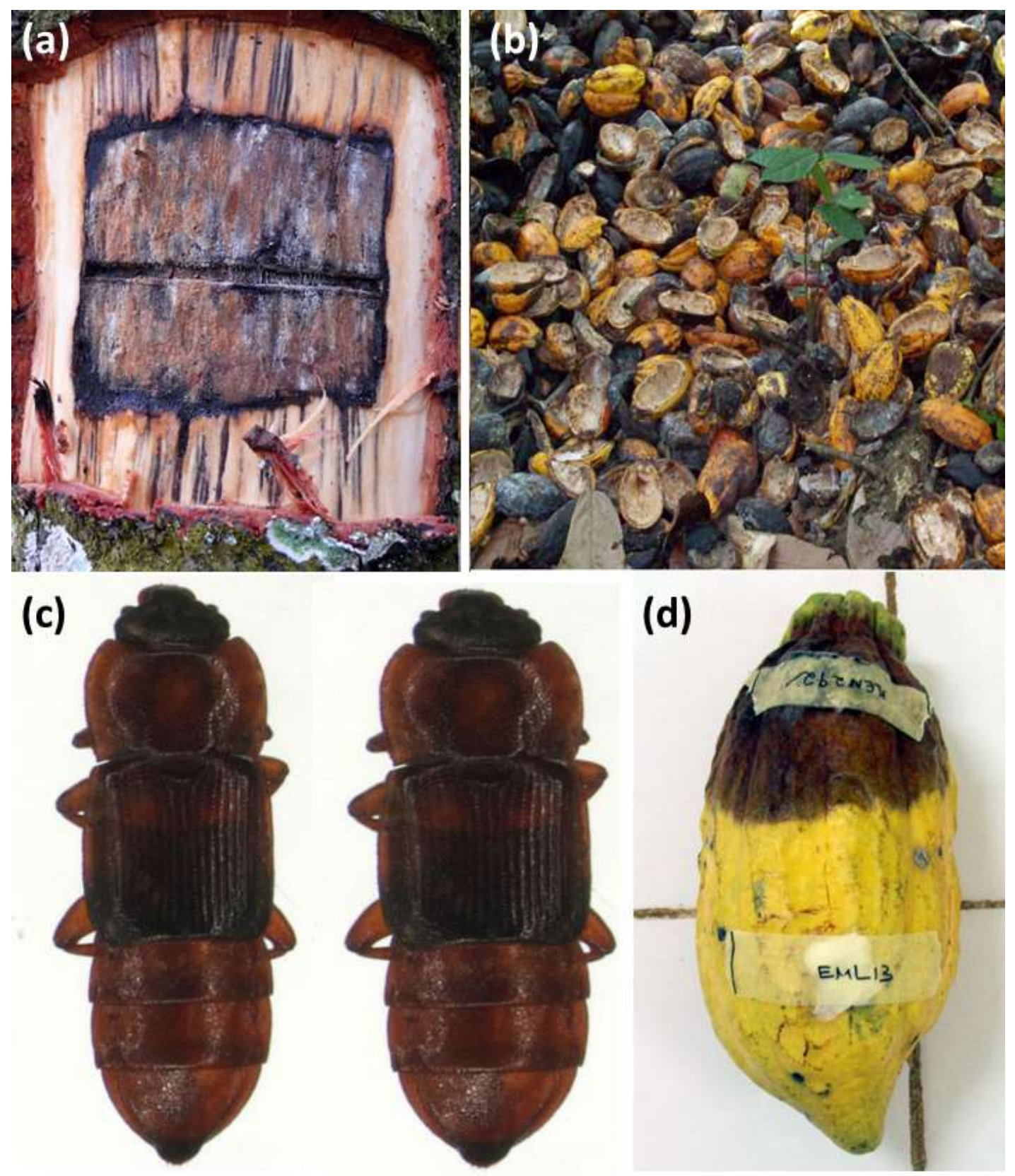

Figure 1 Substrates from which fungi were collected in cacao agroforests in Cameroon. (a) induced fresh wound $(\sim 10 \times 10 \mathrm{~cm})$ with a slit incised in the sapwood of a cacao tree after removal of the bark; (b) cacao pod husk heap; (c) Brachypeplus nitidulid beetles obtained from cacao stem wounds and pod husks; (d) Thielaviopsis ethacetica (top, CMW35028) causing pod rot contrasting with Thielaviopsis cerberus (bottom, CMW35021) after inoculation onto a healthy cacao pod. 
During field visits, all substrates likely to harbour species of Ceratocystidaceae and nitidulid beetles present within or around the study sites were also examined and where appropriate, additional samples (plant material and insects) were collected from these substrates. These specifically included cacao pod husk piles (Figure 1d) abandoned in the plantations by farmers after harvesting the beans in Bokito and Ngomedzap, as well as natural wounds on two tree species, Terminalia mantaly L. and Erythrophleum ivorense A. Chev. (Tali), growing alongside the cacao plots in Ngomedzap. These trees had been recently damaged by a wind storm. Furthermore, seven wind-oriented traps baited with dough and Carpophilus hemipterus pheromone lure (Great Lakes IMP, Vastaburg, Michigan) were set up for $\sim 12 \mathrm{hr}$ at each farm in Ngomedzap. This was in an attempt to capture flying nitidulid beetles from which fungi related to the Ceratocystidaceae could be isolated.

\section{Sample processing and fungal isolation}

Sample processing for fungal isolation included incubation of plant materials under moist conditions to induce further development of fungal structures, and baiting for Ceratocystis species using carrot slices (Moller \& De Vay, 1968a). Pieces of plant material were placed in 90mm-Petri dishes lined with moistened tissue paper. Small chips were taken from the same material and wrapped between two carrot discs pre-treated with streptomycin sulphate (Sigma, Steinheim, Germany). Isolation from Nitidulid beetles was also attempted using carrot-baiting. The insects were initially grouped into morphotypes, and five representatives of each morphotype were individually crushed onto the surface of carrot discs. The remaining specimens were kept in $90 \%$ ethanol for later identification.

Fungi were isolated from processed materials after 7-10 days. Mycelial strands or single masses of ascospores at the tips of ascomata that formed on the surfaces of cacao tissues or on the carrot 
slices, were transferred to $2 \%$ malt extract agar (MEA; Biolab, Midrand, South Africa), supplemented with $\sim 0.01 \mathrm{~g} / \mathrm{L}$ streptomycin sulphate (Sigma, Steinheim, Germany). Isolates were purified by sub-culturing from single hyphal tips, and they were grouped based on their morphotypes. When possible, two isolates, representing each morphotype, were retained per substrate for further analyses.

\section{Molecular characterization and phylogenetic analyses of fungal isolates}

Fungal DNA extraction was conducted following the procedure described by Mbenoun et al. (2014a). Sequence data were generated for the beta tubulin $(\beta-t u b)$ gene region and used as a means of first level sorting of isolates. For this purpose, the $\beta$-tub sequences were aligned using the MUSCLE algorithm implemented in MEGA version 5 (Tamura et al., 2011) and, subsequently, a neighbour joining (NJ) phylogenetic tree was constructed in MEGA. Four to six representatives from different sites and substrates were selected from each clade of the NJ tree for further identification. This led to the selection of 17 isolates (Table 1) for which the internal transcribed spacer regions including the 5.8S rDNA of the ribosomal RNA cluster (ITS) and a portion of the translation elongation factor 1 alpha gene (tef1- $\alpha)$ were also sequenced. The protocols and procedures used for PCR and sequencing were the same as those described by Mbenoun et al. (2014a).

Three sequence datasets representing the ITS, $\beta$-tub and tef1- $\alpha$ loci were prepared for phylogenetic analyses. These included sequences for the 17 selected isolates from Cameroon generated in this study, as well as those retrieved from GenBank, representing closely related reference species identified using NCBI-Blast (http://blast.ncbi.nlm.nih.gov/Blast.cgi) (see Table 1 for GenBank accession numbers). Sequences of Huntiella moniliformopsis (Yuan \& Mohammed) Z.W. de Beer, T.A. Duong \& M.J. Wingf. were used to represent an outgroup 
Table 1 Huntiella species and GeneBank accession numbers of DNA sequences used for phylogenetic analyses

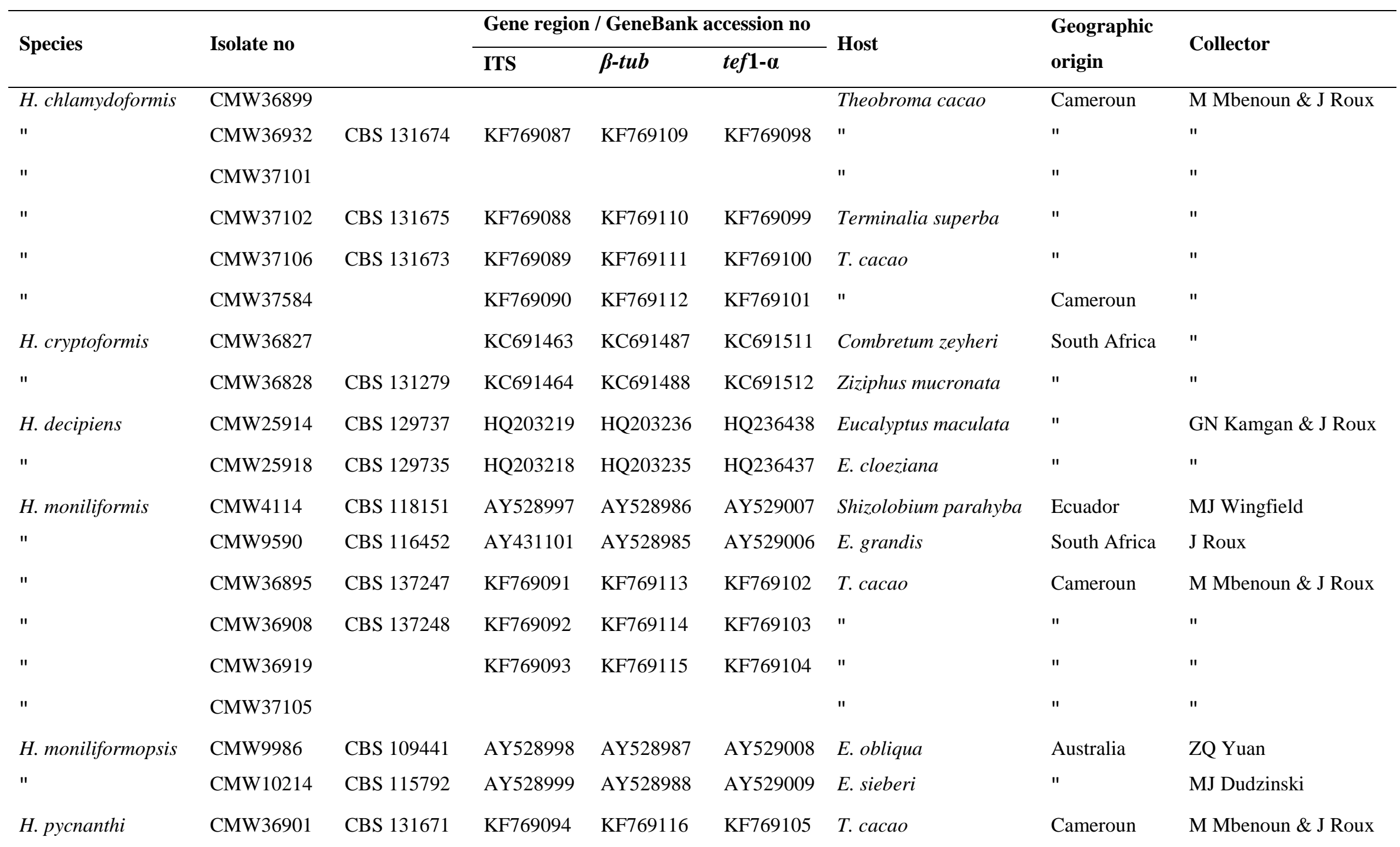




\begin{tabular}{|c|c|c|c|c|c|c|c|c|}
\hline " & CMW36910 & & KF769095 & KF769117 & KF769106 & $"$ & $"$ & $"$ \\
\hline " & CMW36915 & & & & & $"$ & $"$ & $"$ \\
\hline$"$ & CMW36916 & CBS 131672 & KF769096 & KF769118 & KF769107 & $"$ & $"$ & $"$ \\
\hline$"$ & CMW36921 & & KF769097 & KF769119 & KF769108 & $"$ & $"$ & $"$ \\
\hline " & CMW36933 & & & & & $"$ & $"$ & $"$ \\
\hline H. oblonga & CMW23802 & & EU245020 & EU244992 & EU244952 & Acacia mearnsii & South Africa & RN Heath \\
\hline " & CMW23803 & CBS 122291 & EU245019 & EU244991 & EU244951 & $"$ & $"$ & $"$ \\
\hline H. salinaria & CMW25911 & CBS 129733 & HQ203213 & HQ203230 & HQ236432 & E. maculata & $"$ & GN Kamgan \& J Roux \\
\hline " & CMW30703 & CBS 129734 & HQ203214 & HQ203231 & HQ236433 & E. saligna & $"$ & $"$ \\
\hline H. savannae & CMW173298 & & EF408553 & EF408567 & EF408573 & Ter. sericea & $"$ & $"$ \\
\hline " & CMW17300 & CBS 121151 & EF408551 & EF408565 & EF408572 & A. nigrescens & $"$ & $"$ \\
\hline H. sublaevis & CMW22444 & CBS 122518 & FJ151430 & FJ151464 & FJ151486 & Ter. ivorensis & Ecuador & MJ Wingfield \\
\hline " & CMW22449 & CBS 122517 & FJ151431 & FJ151465 & FJ151487 & $"$ & $"$ & $"$ \\
\hline H. tribiliformis & CMW13011 & CBS 115867 & AY528991 & AY529001 & AY529012 & Pinus merkusii & Indonesia & $"$ \\
\hline " & CMW13012 & CBS 118242 & AY528992 & AY529002 & AY529013 & $"$ & $"$ & $"$ \\
\hline H. tyalla & CMW28917 & & HМ071899 & HМ071909 & HQ236448 & E. grandis & Australia & GN Kamgan \\
\hline " & CMW28920 & & HМ071896 & HМ071910 & HQ236449 & " & $"$ & $"$ \\
\hline H. ceramica & CMW15245 & CBS 122299 & EU245022 & EU244994 & EU244926 & $"$ & Malawi & RN Heath \& J Roux \\
\hline " & CMW15248 & CBS 122300 & EU245024 & EU244996 & EU244928 & $"$ & $"$ & $"$ \\
\hline
\end{tabular}


taxon. For all three datasets, alignments were generated using MAFFT (http://www.align.bmr.kyushu-u.ac.jp/mafft/online/server/) and edited in MEGA. Single gene alignments were thereafter concatenated into a super-alignment, which was then used for multigene phylogenetic inference (http://purl.org/phylo/treebase/phylows/study/TB2:S16363).

Two parallel multigene phylogenetic reconstructions were conducted, using the maximum likelihood (ML) and maximum parsimony (MP) approaches, respectively. MP analyses were performed using PAUP version 4.0b10* (Swofford, 2002) and involved only parsimonyinformative characters, including gaps as a fifth character state. All characters were assigned the same weight and considered unordered. Trees were generated via a heuristic tree search with 1000 random stepwise addition replicates and tree-bisection-reconstruction (TBR) branchswapping. All equally most parsimonious trees (MPTs) were saved. The tree length (TL), consistency $(\mathrm{CI})$, retention $(\mathrm{RI})$ and rescaled consistency $(\mathrm{RC})$ indexes of the MPTs were calculated. ML analyses were performed online, using PhyML 3.0 (http://www.atgc-

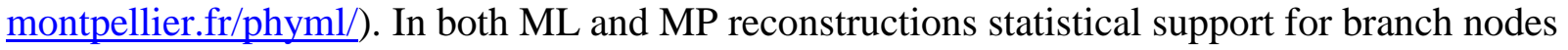
was determined by performing 1000 bootstrap analyses replicates.

Unnamed clades with significant statistical support emerging from multigene phylogenetic analyses were considered as putatively undescribed taxa. For these candidate new taxa, the relationships with their closest known relatives, based on single gene loci, was investigated. This was achieved using unrooted MP analyses in MEGA, and made it possible to also determine the number of fixed nucleotide changes between the new taxa and their closest relatives.

\section{Growth studies and culture morphology}

For each of the putatively new fungal species identified in the phylogenetic analyses, two representative isolates from different sites were chosen and used in growth studies at different 
temperatures. Temperature optima, minima and maxima were determined for the fungi by measuring colony diameters at six different temperatures, ranging from 10 to $35^{\circ} \mathrm{C}$ at $5{ }^{\circ} \mathrm{C}$ intervals. Five replicate plates were prepared for each isolate at each temperature, by transferring agar plugs (eight $\mathrm{mm}$ in diameter) from the margins of actively growing cultures to the centres of 90-mm Petri dishes containing fresh, sterile 2\% MEA. Plates were incubated at the test temperatures in the dark for three days. Measurements were taken along two perpendicular axes centred on the plugs, and averages and standard deviations were computed. Optimum, minimum and maximum temperature intervals were determined from growth curves.

Morphological descriptions were made using 1-2 wk old cultures of the isolates utilized for the growth studies, maintained at their optimum growth temperatures. Descriptions of colony colour were based on the mycological colour charts of Rayner (1970). Fungal structures were examined and described using a Zeiss Axioskop microscope (Carl Zeiss Ltd, Germany), fitted with a HRc Axiocam digital camera and Axiovision 3.1 particle sizing software. Slides for microscopy were prepared by placing relevant structures in $85 \%$ lactic acid. Where possible, 50 measurements were taken for each taxonomically informative character for holotype specimens, and 10 measurements for each of two paratypes of new species. Species means and standard deviation values were computed for each character. These measurements are presented as the extremes in brackets and the range represented by the mean over all holotype and paratype measurements, plus or minus the standard deviations.

Isolates selected as holotypes as well as one or two paratypes of new species were deposited as living cultures with the Centraalbureau voor Schimmelcultures (CBS), the Netherlands and dried down replicate specimens were deposited with the National collection of fungi (PREM), Pretoria, South Africa. 


\section{Incidence of the Ceratocystidaceae in cacao fields}

After identification, the number of isolates representing each fungal species collected from the various sites and substrates was determined. The isolation frequency from cacao stem wounds was then calculated for each study site. This was done in order to assess the possible influence that agroecological conditions and management practices may have on the incidence of the Ceratocystisdaceae in cacao plantations.

\section{Identification of nitidulid beetles}

Identification of insects was primarily based on morphology, facilitated by comparing specimens with those in the collection of nitidulid beetles maintained at the Forestry and Agricultural Biotechnology Institute (FABI), University of Pretoria. In addition, for selected specimens representing each nitidulid morphotype from Cameroon, DNA was extracted using the prepGEM $^{\mathrm{TM}}$ Insect (zyGEM) DNA extraction kit, following the manufacturer's instructions. Subsequently, the mitochondrial cytochrome oxydase I (MT-CO1) gene region was amplified and sequenced using the universal primer combination Cl-J-2183: 5'-

CAACATTTATTTTGATTTTTTGG-3'/TL2-N-3014: 5'CCAATGCACTAATCTGCCATATTA-3' (Simon et al., 1994). PCR reactions were prepared in

a $25 \mu \mathrm{L}$ final volume, with MyTaq ${ }^{\mathrm{TM}}$ (Bioline) DNA polymerase and Reaction Buffer, following the manufacturer's instructions. The thermal cycling conditions included 5 min at $96^{\circ} \mathrm{C}$ for initial denaturation, 35 cycles of $60 \mathrm{~s}$ at $94{ }^{\circ} \mathrm{C}, 60 \mathrm{~s}$ at $50{ }^{\circ} \mathrm{C}$ and $90 \mathrm{~s}$ at $72{ }^{\circ} \mathrm{C}$, and final extension at $72{ }^{\circ} \mathrm{C}$ for $10 \mathrm{~min}$. All other steps involved in the sequencing procedure were the same as those described by Mbenoun et al. (2014a). MT-CO1 sequences were compared based on NJ algorithms in MEGA and evaluated against the GenBank database using NCBI-Blast. 


\section{Pathogenicity trials}

The pathogenicity of all fungal species recovered in this study was assessed using inoculations on branches of mature cacao trees in the field and detached cacao fruits in the laboratory. Each species was represented by two isolates. Cultures used to produce inoculum were maintained on MEA for $10 \mathrm{~d}$ at room temperature. Inoculations were performed by making wounds on the various plant organs using a sterile $7 \mathrm{~mm}$ cork borer to remove the bark on branches, or outer cortex of fruit tissue. Subsequently, 7-mm-diameter agar plugs taken from the margins of the fungal cultures were used to fill in the wounds, mycelium facing the cambium or inside of the fruit. Sterile MEA was used as a negative control. Inoculated wounds were covered with Parafilm (or with humidified cotton wool for fruits) to prevent desiccation and contamination.

Field inoculation of cacao branches were conducted at Ngomedzap, in the same cacao stands where some of the isolates had been collected. Ten cacao trees were selected and one lignified branch (10-15 $\mathrm{mm}$ in diameter) per tree was inoculated for each treatment. Inoculated branches were cut from the trees after six weeks, and lesion lengths were measured. These included lesions on the surface of the bark and those on the cambium after removing the bark. To confirm the association of observed lesions with the fungal strains used, re-isolations were done by plating small pieces of symptomatic tissue, taken from the edges of lesions on randomly selected branches, onto MEA. Resultant isolates were identified based on morphology.

The field inoculation trial was repeated once. The aggressiveness of isolates tested was compared by submitting cambium lesion lengths (CLL) and bark lesion lengths BLL) to one way analyses of variance (ANOVA) and TukeyHSD multiple range test. Prior to these analyses, the Bartlett test of homogeneity of variances was performed to assess whether data from the two replicated 
experiments could be combined. All statistical analyses were performed using R statistical software (http://www.R-project.org/).

Two independent fruit inoculation experiments were carried out in the laboratory, applying a completely randomized design. Each experiment included 22 mature pods from the same cacao cultivar, and two inoculations were made per pod at the stylar and peduncular ends. Inoculated pods were incubated at room temperature in plastic boxes lined with moist paper. They were examined for signs of rotting after $10 \mathrm{~d}$. Where rotting had developed, re-isolation of the inoculated fungus was attempted by transferring a piece of symptomatic fruit cortex from the margin of the lesion onto MEA, and the resultant isolates were identified based on morphology.

\section{Results}

\section{Field observations and collections}

Two weeks after they were established, artificially induced stem wounds had developed symptoms of fungal infection, with variable levels of severity. Wounds on cacao (Figure 1a-c) were typically characterized by a dark brown discoloration on the surface of the exposed cambium. Abundant mycelial growth covered the wounds and ascomata resembling those formed by species of Ceratocystidaceae were observed in and around the central slit in the sapwood on some trees. When the mycelial mat was pealed from the surface of the wounds, substantial brown streaking of the sapwood was noted. The streaks extended vertically, reaching up to $20 \mathrm{~cm}$ in length. More extensive internal discoloration developed from the slits, deeper into the sapwood. Cacao stem wounds were generally drier in Bokito, showing less severe internal discoloration as compared with those at the other two sites. 
Limited internal discoloration was observed on Terminalia shade trees wounded at Ngomedzap. In contrast, Cassia and Ceiba trees at Nkoemvone and Bokito respectively, showed no discoloration in the sapwood, although some mycelial growth and a few ascomata were observed on the exteriors of the wounds on Ceiba trees. The exposed cambium on Cassia trees was superficially covered with a black stain (Supplementary material - Figure S2), which could have prevented wound infection of on this host. Ascomata were observed on naturally damaged Ter. mantaly and E. ivorense trees growing alongside the cacao plots at Ngomedzap. Wood samples carrying abundant, fresh mycelium and ascomata were collected from these trees for fungal isolation and identification.

Abundant fungal growth was observed on abandoned pod husks (Figure 1d) and samples were collected from them at Bokito and Ngomedzap. The endosperms of fresh pod husks were generally covered with a diverse fungal flora (Figure 1e), including species of Ceratocystidaceae and other ophiostomatoid fungi (Wingfield et al. 1993; Seifert et al. 2013).

Nitidulid beetles were observed on most of the substrates examined in this study. These insects (larval and adult stages) were especially abundant in cacao pod husk piles where they appeared to find ideal conditions for breeding. Nitidulid beetles were also found colonizing stem wounds on cacao where they appeared shortly after the wounds were made. At Nkoemvone, large numbers (up to 15 per wound) of nitidulid beetles were recovered under bark flaps on cacao, while only two to three individuals (representing a different morphotype) were found on some wounded Cassia trees. No insects were collected from wounds on Ceiba trees and only a small number of insects were caught in the traps $(<3$ per trap, on average).

In total, 83 fungal isolates related to the Ceratocystidaceae were collected from cacao agroforests (Table 2). These included 53 isolates from Ngomedzap, 22 from Bokito and 10 from 
Table 2 Number of isolates and substrates from which species of Ceratocystidaceae were collected in cacao agroforests in Cameroon

\begin{tabular}{|c|c|c|c|c|c|c|}
\hline \multirow{2}{*}{ Substrate } & \multirow{2}{*}{ Study site } & \multicolumn{3}{|c|}{ Huntiella } & \multicolumn{2}{|c|}{ Thielaviopsis } \\
\hline & & H. chlamydoformis & H. moniliformis & H. pycnanthi & Th. cerberus & Th. ethacetica \\
\hline \multirow[t]{3}{*}{ Cacao stem wounds } & Bokito & 4 & 2 & 7 & 4 & - \\
\hline & Nkoemvone & 3 & 5 & 2 & - & - \\
\hline & Ngomedzap & 6 & 10 & 4 & - & 2 \\
\hline \multirow[t]{2}{*}{ Cacao pod husks } & Bokito & - & - & - & - & 3 \\
\hline & Ngomedzap & 4 & - & - & - & 9 \\
\hline $\begin{array}{l}\text { Terminalia stem } \\
\text { wounds }\end{array}$ & Ngomedzap & 3 & 5 & - & - & - \\
\hline Other tree wounds & Ngomedzap & 3 & 3 & - & - & 2 \\
\hline Nitidulid beetles & Ngomedzap & - & - & - & - & 2 \\
\hline
\end{tabular}


Nkoemvone. Of these, 49 isolates were obtained from 22 artificially wounded cacao trees, 16 isolates from abandoned cacao pod husks in three plantations, eight isolates from four wounded Terminalia shade trees, and eight isolates from naturally damaged E. ivorense and Ter. mantaly trees alongside cacao plantations. In addition, two isolates were collected from two of 35 nitidulid beetles caught infesting cacao pod husks and stem wounds. No fungal isolates related to the Ceratocystidaceae were obtained from wounded Cassia trees, and while some ascomata were observed on Ceiba trees, these fungi could not be isolated from this host.

\section{Phylogenetic analyses of fungal isolates}

Based on general morphological characteristics, all fungal isolates collected in this study could broadly be placed in either of two genera, Huntiella Z.W. de Beer, T.A. Duong \& M.J. Wingf. and Thielaviopsis Went, recently defined by de Beer et al. (2014). Isolates related to Thielaviopsis included Th. cerberus (Mbenoun, M.J. Wingf. \& Jol. Roux) Z.W. de Beer, T.A. Duong \& M.J. Wingf. and Th. ethacetica Went, previously identified by Mbenoun et al. (2014a), using a combination of comparative morphology, mating studies and multigene phylogenies. Isolates related to Huntiella were of unknown identity and only these were included in phylogenetic reconstructions.

The concatenated alignment matrix for Huntiella isolates included 38 sequences and 1575 characters. There were 222 parsimony-informative characters and MP analyses of these resulted in 15 MPTs of 323 steps $(\mathrm{CI}=0.84, \mathrm{RI}=0.97, \mathrm{RC}=0.82)$. The Cameroonian isolates were resolved into three main clades (Figure 2), with strong statistical support (83-92\%). Clade 1 included isolates representing H. moniliformis (Hedgc.) Z.W. de Beer, T.A. Duong \& M.J. Wingf., while the other two clades were distinct from those delineated by known species used as references in the analyses. The two unnamed new clades were related to the Huntiella African lineage 
(Mbenoun et al., 2014b). Clade 2 had a basal position in the lineage and was most closely related to H. decipiens (Kamgan \& Jol. Roux) Z.W. de Beer, T.A. Duong \& M.J. Wingf., H. salinaria (Kamgan \& Jol. Roux) Z.W. de Beer, T.A. Duong \& M.J. Wingf. and H. ceramica (R.N. Heath \& Jol. Roux) Z.W. de Beer, T.A. Duong \& M.J. Wingf., while Clade 3 was monophyletic with $H$.

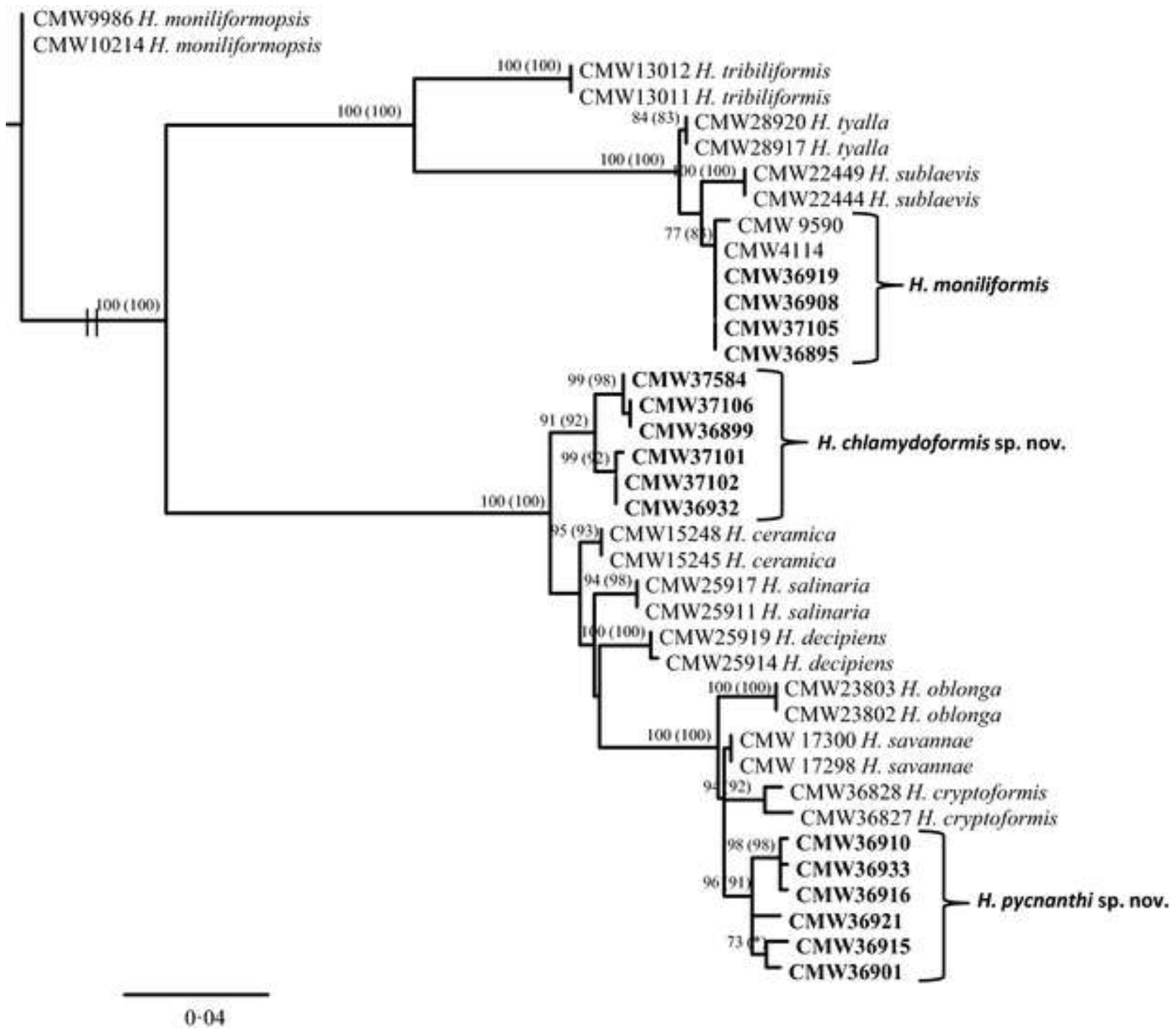

Figure 2 Phylogenetic tree derived from maximum likelihood analysis of combined ITS, $\beta$-tub and tef1- $\alpha$ gene sequences of Huntiella isolates from cacao agroforests in Cameroon together with sequences of selected reference species. Bootstrap support values $\geq 70 \%$ are indicated next to branch nodes, including in brackets those from maximum parsimony analysis. 
savannae (Kamgan \& Jol. Roux) Z.W. de Beer, T.A. Duong \& M.J. Wingf., H. oblonga (R.N. Heath \& Jol. Roux) Z.W. de Beer, T.A. Duong \& M.J. Wingf. and H. cryptoformis (Mbenoun \& Jol. Roux) Z.W. de Beer, T.A. Duong \& M.J. Wingf. The new clades showed substantial polymorphism (Figure 2), each including two statistically well-supported sub-clades. The phylogeny resulting from ML analyses was concordant with that from MP analyses in all respects (tree topology, relationship among taxa and statistical support) and generally produced stronger bootstrap values for branch nodes (Figure 2).

When considered separately, each of the gene loci used in this study could discriminate the two unnamed clades from Cameroon, initially identified using a combined multigene data set.

However, these markers showed variable resolution between the new taxa and their respective closest related species. The ITS produced no resolution, whereas the $\beta$-tub and tefl- $\alpha$ genes could either discriminate only Clades 3 or Clade 2 respectively, showing from four to 14 fixed nucleotide changes (Supplementary material - Figure S3). It also emerged that the polymorphism observed within Clade 2 and Clade 3 in the multigene tree was supported only by these same respective genes, prohibiting further consideration of their sub-clades as potential cryptic species based on available data.

\section{Culture and morphological characteristics}

Isolates in Clade 2 grew optimally at $25^{\circ} \mathrm{C}$, covering $56-61 \mathrm{~mm}$ within $3 \mathrm{~d}$ on MEA, whereas no growth was observed at 10 and $35^{\circ} \mathrm{C}$. They developed fluffy colonies with aerial mycelium changing from hyaline to hazel $\left(17^{\prime \prime \prime}\right.$ b) with age. Hyphae were smooth, without constriction at the septa. Where ascomata had formed, they were generally distributed in a stellar fashion around the centre of the colony. The general structure of the ascomata was reminisecent of $H$. decipiens, including a relatively thick collar plate connecting the ascomatal necks and bases. The surfaces of 
ascomatal bases were rough, but sharp conical spines known for H. decipiens and other Huntiella species were not observed. Unlike any other Huntiella species, aging cultures of isolates in Clade 2 formed thick-walled chlamydospores. These structures appeared to evolve from transformation of mycelial cells. This distinguishes them from aleurioconidia, which are formed basipetally from specialized conidiogenous cells in other genera of Ceratocystidaceae such as Ceratocystis, Chalaropsis and Thielaviopsis (Mbenoun et al., 2014a; de Beer et al., 2014)

The optimal growth temperature for isolates in Clade 3 was $30^{\circ} \mathrm{C}$. The average colony diameter was $61-75 \mathrm{~mm}$ after $3 \mathrm{~d}$ at $30{ }^{\circ} \mathrm{C}$ on MEA. Substantial residual growth was noted at $35^{\circ} \mathrm{C}$, but no growth at $10^{\circ} \mathrm{C}$. Cultures had fluffy, aerial mycelium, changing from hyaline or white to smoke grey (21',',d ) with age. Hyphae were smooth and granular, without constrictions at the septa. Ascomata were randomly distributed on the agar plates and their bases were more globoid and lighter in colour than those of closely related species. The disciform collar structures connecting the ascomatal necks and bases, common to most species in the African lineage of Huntiella, was absent in isolates of Clade 3.

\section{Taxonomy}

Based on their nucleotide divergence, as revealed by phylogenetic analyses, combined with some distinct morphological characteristics, the Cameroonian Huntiella isolates from cacao agroforests and residing in Clade 2 and Clade 3 represent two previously undescribed species. They are described here respectively as $H$. chlamydoformis sp. nov. and $H$. pycnanthi sp. nov.

Huntiella chlamydoformis Mbenoun \& Jol. Roux sp. nov., Figure 3.

MycoBank MB 807094 


\section{Etymology}

The name refers to the chlamydospores formed by this species, a feature not common in the genus Huntiella.
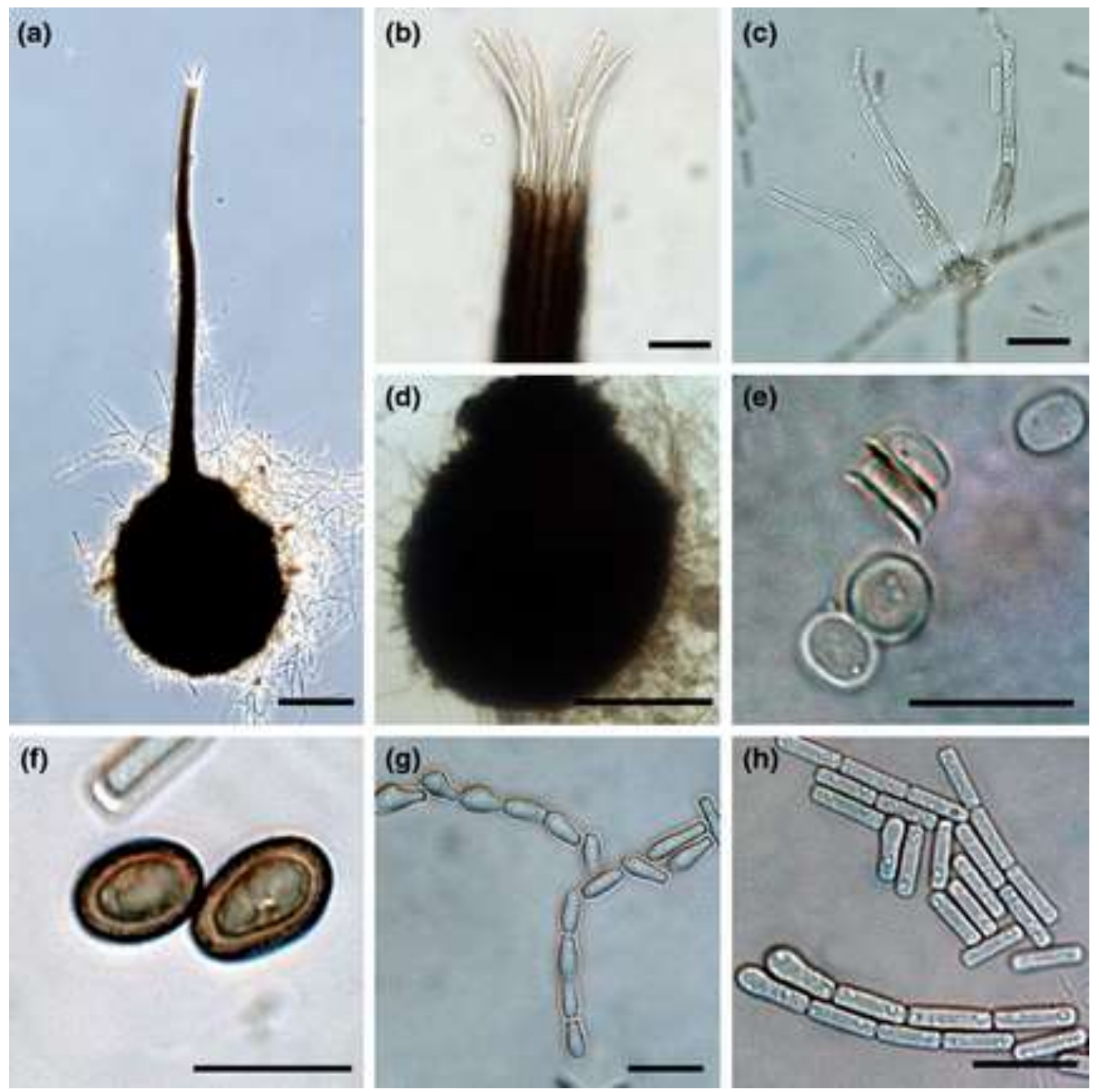

Figure 3 Morphological characteristics of Huntiella chlamydoformis sp. nov. (a) ascomata with globose base and extended neck; (b) tip of ascomatal neck showing divergent ostiolar hyphae; (c) monophialidic conidiophores; (d). ascocarp base showing bulbous collar structure at neck base; (e) ascospores in side (hat-shaped) and basal views; (f) thick-walled chlamydospores; (g) variform secondary conidia; (h) rectangular primary conidia. Scale bars: a, d = 100 $\mu \mathrm{m} ; \mathrm{b}, \mathrm{c}, \mathrm{e}, \mathrm{f}, \mathrm{g}, \mathrm{h}=10 \mu \mathrm{m}$. 


\section{Description}

Colonies on MEA fast growing, reaching 50-61 $\mathrm{mm}$ in diameter within $3 \mathrm{~d}$, optimum temperature for growth $25^{\circ} \mathrm{C}$, no growth at $10{ }^{\circ} \mathrm{C}$ and $35^{\circ} \mathrm{C}$. Mycelium fluffy and superficial, initially hyaline to white, turning to hazel $\left(17^{\prime \prime}\right.$ ' b) with age. Hyphae smooth without constrictions at septa. Ascomata with bulbous bases and long necks, formed superficially on substrate, generally distributed in a stellar fashion around the centre of the colony. Ascomatal bases dark brown, globose or subglobose, (174-)204-298(-382) ×(155-)180-264(-363) $\mu \mathrm{m}$. Ascomatal necks dark brown, erect or slightly curled, forming a bulbous collar at the junction with ascomatal bases, $(372-) 486-714(-896) \mu \mathrm{m}$ long, $(12-) 15-20(-23) \mu \mathrm{m}$ wide at apices and (30)34-42(-49) $\mu \mathrm{m}$ wide at bases. Ostiolar hyphae hyaline, divergent, (21-)28-43(-51) $\mu \mathrm{m}$ long, Asci not observed. Ascospores accumulating in creamy to yellow droplets at the tips of ascomatal necks, aseptate, cucullate in side view, (5-)6-8 $\mu \mathrm{m}$ wide and 2-3 $\mu \mathrm{m}$ high. Conidiophores occurring solitary or aggregated in small bundles and arising laterally from hyphae, hyaline, monophialidic, (17-)23-33(-45) $\mu \mathrm{m}$ long, 1-3 $\mu \mathrm{m}$ wide at apices and (2-)3-4(-5) $\mu \mathrm{m}$ wide at bases. Primary conidia hyaline, aseptate, rectangular, $(5-) 6-9(-12) \times 1-3 \mu \mathrm{m}$. Secondary conidia hyaline, smooth, aseptate, variable in shape, $(4-) 6-8(-10) \times 2-4(-5) \mu \mathrm{m}$. Chlamydospores cacao brown, thick-walled, aseptate, obovoid, (7-)9-11(-15) $\times(4-) 5-7(-8) \mu \mathrm{m}$. Aleurioconidia not observed.

Type

Holotype of Huntiella chlamydoformis CAMEROON, Centre region, Ngomedzap $\left(3^{\circ} 16^{\prime} 3.5^{\prime \prime} \mathrm{N}\right.$, $\left.11^{\circ} 14^{\prime} 50.4^{\prime \prime} \mathrm{E}\right)$, on wounded stem of Theobroma cacao, December 2009, coll. M. Mbenoun \& J. Roux, PREM 60837 (PREM), culture ex-holotype CMW36932 = CBS 131674. 
Additional specimens examined

CAMEROON, Centre region, Ngomedzap $\left(3^{\circ} 16^{\prime} 3.5^{\prime \prime} \mathrm{N}, 11^{\circ} 14^{\prime} 50.4^{\prime \prime} \mathrm{E}\right)$, on wounded stem of Terminalia superba, December 2009, coll. M. Mbenoun \& J. Roux, dry specimen PREM 60838, living culture CMW37102 = CBS 131675; on wounded stem of Theobroma cacao, December 2009, coll. M. Mbenoun \& J. Roux, living culture, CMW37101; Centre Region, Bokito $\left(4^{\circ} 30^{\prime} 16.7^{\prime \prime} \mathrm{N}, 11^{\circ} 4^{\prime} 44.9^{\prime \prime} \mathrm{E}\right)$, on wounded stem of Theobroma cacao, December 2009, coll. M. Mbenoun \& J. Roux, living culture, CMW37106; South region, Nkoemvone, IRAD research station $\left(2^{\circ} 49^{\prime} 10.5^{\prime \prime} \mathrm{N}, 11^{\circ} 7^{\prime} 57.9^{\prime \prime} \mathrm{E}\right)$, on wounded stem of Theobroma cacao, December 2009, coll. M. Mbenoun, dry specimen PREM 60836, living culture CMW37584 = CBS 131673; on wounded stem of Theobroma cacao, December 2009, coll. M. Mbenoun, living culture, CMW36899.

Notes: The most distinctive morphological characteristic of $H$. chlamydoformis is the production of chlamydospores in aging cultures. In the literature treating Huntiella, these structures are mentioned only in the C.M.I. descriptions of H. moniliformis (Morgan-Jones et al., 1967). H. chlamydoformis can also be distinguished from closely related species by its relatively larger ascomata. The tef1- $\alpha$ was the only gene that could differentiate $H$. chlamydoformis and $H$. ceramica. The two species had identical sequences at the ITS and $\beta$-tub loci.

Huntiella pycnanthi Mbenoun \& Jol. Roux sp. nov., Figure 4

MycoBank MB 807095 


\section{Etymology}

The name refers to the morphological similarities between this species and the fungus treated by Luc (1952) as a morphological variant of H. moniliformis, and isolated from logs of Pycnanthus angolensis (Welw.) Warb in Cameroon.
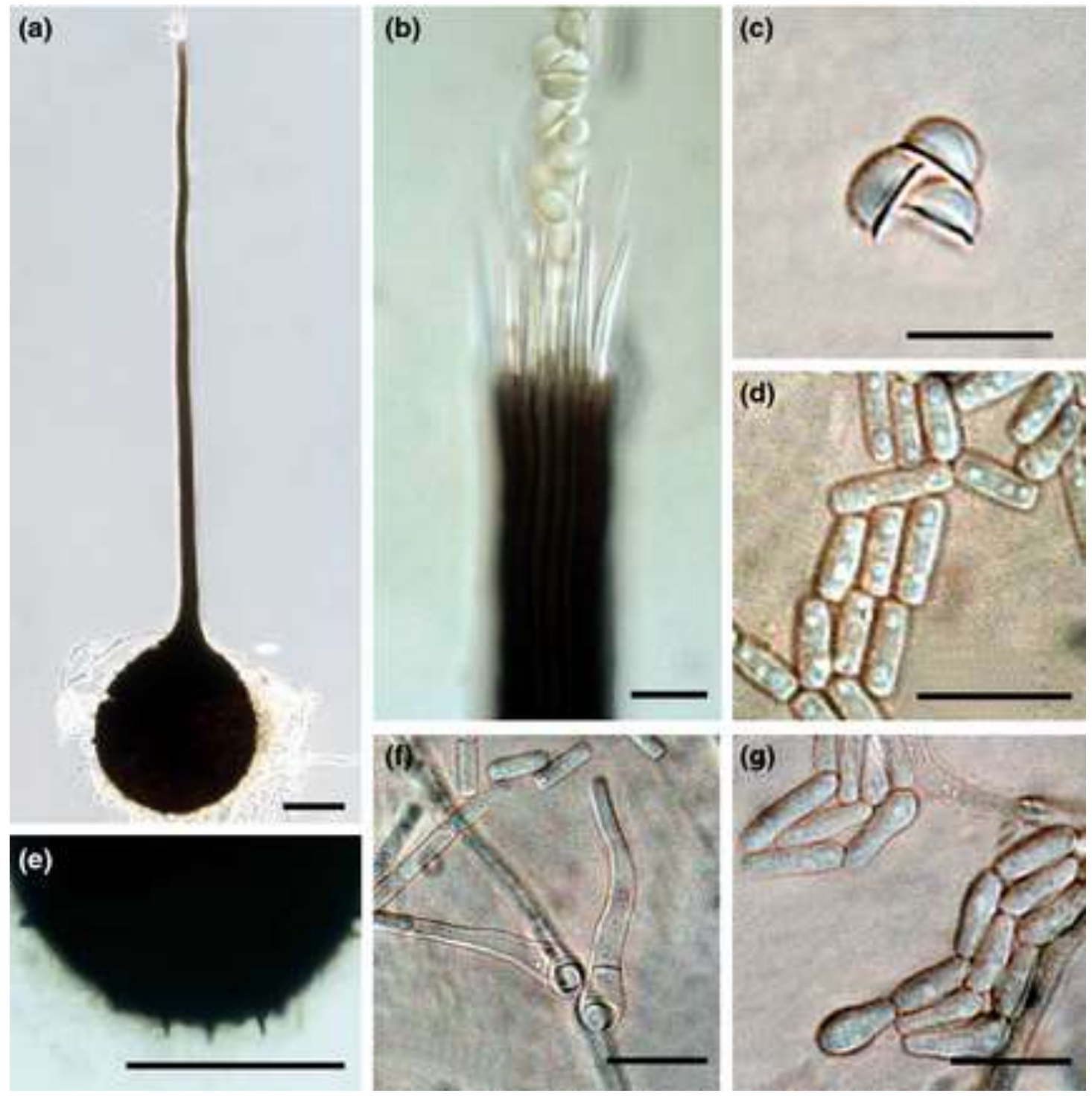

Figure 4 Morphological characteristics of Huntiella pycnanthi sp. nov. (a) ascomata with globose base and extended neck; (b) tip of ascomatal neck with divergent ostiolar hyphae extruding ascospores in string; (c) ascospores in basal and side (hat-shaped) views; (d) bacilliform primary conidia; (e) conical spines on the surface of ascocarp base; (f) monophialidic conidiophores; (g) variform secondary conidia. Scale bars: a, e $=100 \mu \mathrm{m} ; \mathrm{b}, \mathrm{c}, \mathrm{d}, \mathrm{f}, \mathrm{g}=10 \mu \mathrm{m}$. 


\section{Description}

Colonies on MEA fast growing, reaching $61-75 \mathrm{~mm}$ in diameter within $3 \mathrm{~d}$, optimum temperature for growth $30{ }^{\circ} \mathrm{C}$, substantial growth at $35^{\circ} \mathrm{C}$ but no growth at $10{ }^{\circ} \mathrm{C}$. Mycelium fluffy and superficial, initially hyaline to white turning smoke grey $\left(21^{\prime \prime,}\right.$, d) with age. Hyphae smooth and granular, without constrictions at septa. Ascomata perithecial with bulbous bases and long necks, formed superficially on substrate, randomly distributed. Ascomatal bases light brown, globose to subglobose, $(145-) 182-270(-339) \times(137-) 187-259(-259) \mu \mathrm{m}$, ornamented with scattered conical spines. Ascomatal necks dark brown, erect or slightly curled, disciform structure connecting ascomatal bases and necks absent, (391-)529-817(-1045) $\mu \mathrm{m}$ long, (15)17-23(-27) $\mu \mathrm{m}$ wide at apices and (33-)37-47(-58) $\mu \mathrm{m}$ wide at bases, ostiolar hyphae hyaline, divergent, (30-)39-51(-67) $\mu \mathrm{m}$ long. Asci not observed. Ascospores accumulating in creamy to yellow droplets at the tips of ascomatal necks, aseptate, cucullate in side view, $(5-) 6-7(-8) \mu \mathrm{m}$ wide and 3-4 $\mu \mathrm{m}$ high. Conidiophores occurring mostly solitary and arising laterally from hyphae, hyaline, monophialidic (16-)23-35(-51) $\mu \mathrm{m}$ long, 2-3 $\mu \mathrm{m}$ wide at apices and 3-4(-5) $\mu \mathrm{m}$ wide at bases. Primary conidia hyaline, aseptate, cylindrical, (4-)5-7(-11) $\times 1-2 \mu \mathrm{m}$.

Secondary conidia hyaline, aseptate, oblong to cylindrical, (4-)5-7(-9) × 2-4(-5) $\mu \mathrm{m}$. Aleurioconidia and chlamydospores not observed.

Type

Holotype of Huntiella pycnanthi: CAMEROON, Centre Region, Bokito (4³0'16.7'N, $11^{\circ} 4^{\prime} 44.9^{\prime \prime} \mathrm{E}$ ), on wounded stem of Theobroma cacao, December 2009, coll. M. Mbenoun \& J. Roux, PREM 60835 (PREM), culture ex-holotype CMW36916 = CBS 131672. Additional specimens examined 
CAMEROON, Centre Region, Bokito $\left(4^{\circ} 30^{\prime} 16.7^{\prime \prime} \mathrm{N}, 11^{\circ} 4^{\prime} 44.9^{\prime \prime} \mathrm{E}\right)$, on wounded stem of Theobroma cacao, December 2009, coll. M. Mbenoun, living cultures, CMW36910, CMW36915; Ngomedzap ( $\left.3^{\circ} 16^{\prime} 3.5^{\prime \prime} \mathrm{N}, 11^{\circ} 14^{\prime} 50.4^{\prime \prime} \mathrm{E}\right)$, December 2009, on wounded stem of Theobroma cacao, coll. M. Mbenoun \& J. Roux, living cultures, CMW36921, CMW36933; South Region: Nkoemvone, IRAD research station $\left(2^{\circ} 49^{\prime} 10.5^{\prime \prime} \mathrm{N}, 11^{\circ} 7^{\prime} 57.9^{\prime \prime} \mathrm{E}\right.$, ) on wounded stem of Theobroma cacao, December 2009, coll. M. Mbenoun, dry specimen PREM 60834, living culture CMW36901 = CBS 131671.

Notes: Luc (1952) identified four morphological variants of Huntiella moniliformis (then treated as Ophiostoma moniliforme) that he named the "Theobroame", "Pycnanthi" and "Davidsonii" forms as distinct from the original "Typica" from. The description made of the Pycnanthi form matches closely with the characteristics of $H$. pycnanthi. The two fungi might represent the same species, occurring within the same geographic range. $H$. pycnanthi differs from its closest relatives by the structure of its ascomata, which are characterized by lighter bases and the absence of the disciform collar structure connecting the ascomatal bases and necks. H. pycnanthi is phylogenetically best-circumscribed by the $\beta$-tub gene while the ITS shows no difference with H. cryptoformis, $H$. oblonga and H. savannae.

\section{Diversity and incidence of the Ceratocystidaceae in cacao fields}

The diversity of Ceratocystidaceae recovered from cacao agroforests in Cameroon (Table 2) encompassed five species in two genera Huntiella (H. chlamydoformis, H. moniliformis, and $H$. pycnanthi) and Thielaviopsis (Th. cerberus and Th. ethacetica). Of the three sites investigated in this study, Bokito had the greatest species richness, including all five species as compared to four and three for Ngomedzap and Nkoemvone respectively. Th. cerberus was recovered only at Bokito and Th. ethacetica was not found at Nkoemvone. Huntiella species were predominant on 
tree wounds, whereas Th. ethacetica was most abundant on cacao pod husks and scarce on wounded trees.

The occurrence of Ceratocystidaceae on cacao stem wounds ranged from $50 \%$ at Nkoemvone, to $60 \%$ at Bokito and $80 \%$ at Ngomedzap. Variation was also observed among sites regarding the incidence of the five species recovered on cacao stem wounds (Figure 5). H. pycnanthi and $H$. moniliformis were the most and least prevalent respectively at Bokito, contrasting with Ngomedzap and Nkoemvone where $H$. moniliformis was dominant and $H$. pycnanthi rare. The only species that occurred widely across sites was H. chlamydoformis. Each of the Thielaviopsis species was found on cacao stem wounds only at one site, Th. cerberus from two trees at Bokito and Th. ethacetica from one tree at Ngomedzap.

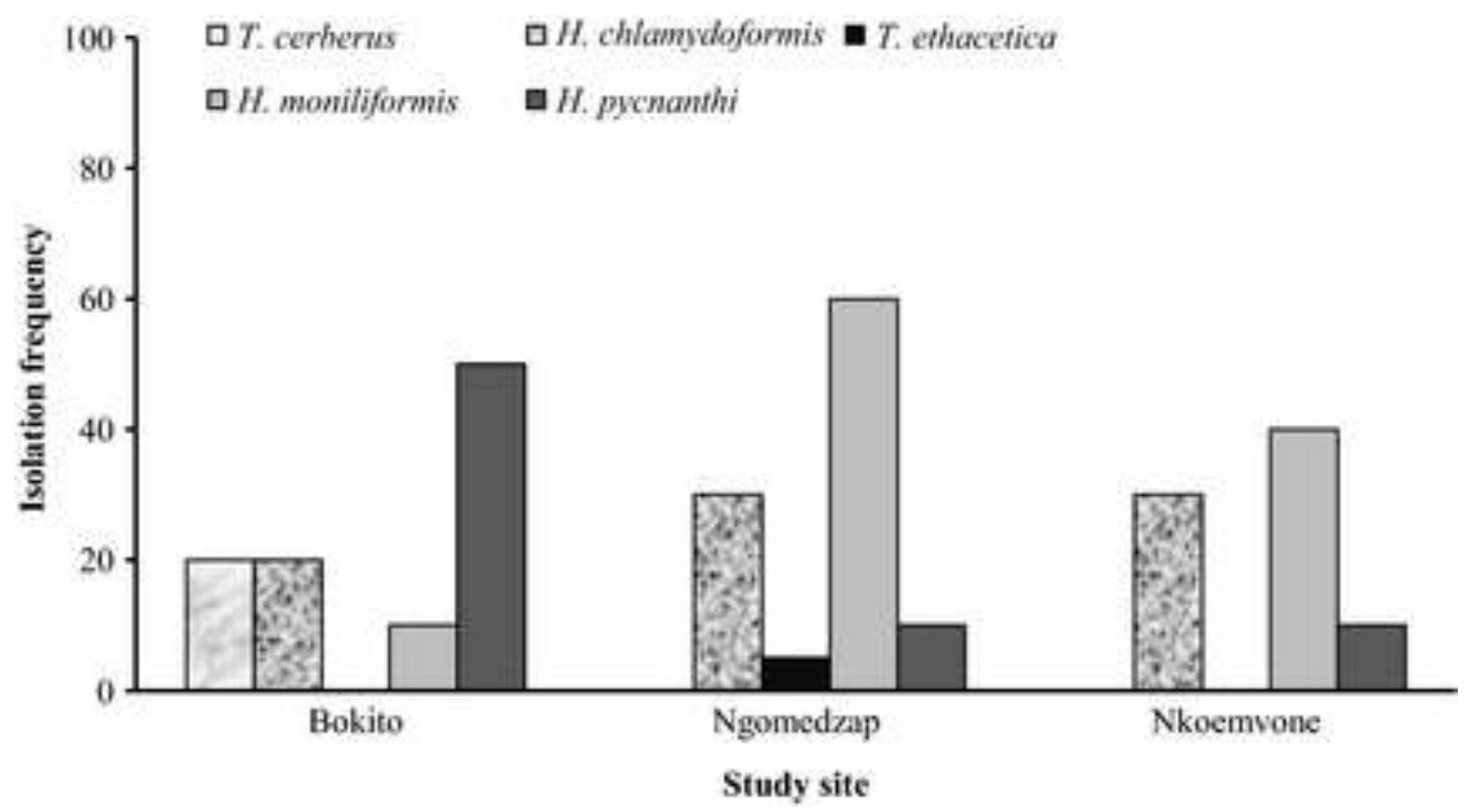

Figure 5 Incidence of the Ceratocystidaceae in cacao agroforests across study sites based on isolation frequencies on artificially induced wounds on cacao stems. 


\section{Identification of nitidulid beetles}

Nitidulid beetles morphologically resembling Brachypeplus species were the most common insects associated with species of Ceratocystidaceae in cacao agroforests. These insects were collected from artificially induced stem wounds and other naturally occurring wounds on trees, as well as cacao pod husks. DNA sequence variation of the MT-CO1 gene (Supplementary material - FigureS4) showed that the collected insects represented at least three species of Brachypeplus (GenBank accessions: KF769077, KF769078, KF769079, KF769080, KF769081, KF769082). Other less commonly occuring nitidulid beetles found in cacao agroforests included Carpophilus species (GenBank accessions: KF769083, KF769084) from wind-oriented traps and wood cracks on E. ivorense, and one unidentified morpho-type (GenBank accessions: KF769085, KF769086) under bark flaps on Cassia trees. DNA sequences of closely related nitidulid species were not found in GenBank and the insects collected in Cameroon could not be further identified.

\section{Pathogenicity tests}

Two isolates for each identified fungal species were evaluated for pathogenicity on cacao. These included CMW35021 and CMW35024 (from cacao stem wounds) for Th. cerberus, CMW35018 (from cacao pod husk) and CMW35028 (from cacao stem wound) for Th. ethacetica, CMW36899 (from cacao stem wound) and CMW37104 (from Terminalia stem wound) for $H$. chlamydoformis, CMW36922 and CMW36895 (from cacao stem wounds) for H. moniliformis, as well as CMW36917 (from cacao stem wound) and CMW36933 (from cacao pod husk) for $H$. pycnanthi. 


\section{Branch inoculations}

The Barlett's Chi squared test showed no significant difference in cambium lesion length (CLL) variance between the two replicated trials $\left(\chi^{2}=0.3427 ; \mathrm{df}=1 ; P=0.5583\right)$. Hence, all CLL data could be pooled-analyzed. In contrast, the null hypothesis of homogeneous variance between trials was rejected $\left(\chi^{2}=13.3176 ; \mathrm{df}=1 ; P=0.0026\right)$ when the test was applied to bark lesion lengths (BLL). Therefore, BLL data for the replicated trials were analyzed separately.

All isolates used in inoculation trials induced distinct lesions in the cambium and sapwood of lignified cacao branches. Results of ANOVA of CLL data $(\mathrm{F}=18.37$; $\mathrm{df}=10 ; P<2 \mathrm{e}-16)$ and

TukeyHSD test (Table 3) showed that there were significant differences in virulence between and among fungal species recovered from cacao agroforests. All isolates induced significantly longer lesions than the sterile agar used for the controls (Table 3). Overall, isolate CMW35028 (Th. ethacetica), from artificially induced stem wounds on cacao, was the most aggressive, followed by isolate CMW36933 (H. pycnanthi) from a cacao pod husk (Table 3, Figure 7).

The lesions measured in the bark were generally shorter than those measured in the sapwood (Table 3). ANOVA showed significant variation in the BLL data for both trial one $(\mathrm{F}=56.02$; $\mathrm{df}$ $=10 ; P<2 \mathrm{e}-16)$ and trial two $(\mathrm{F}=43.94 ; \mathrm{df}=10 ; P<2 \mathrm{e}-16)$. All isolates produced significantly longer lesion as compared to the control and isolates CMW35028 (Th. ethacetica) and CMW36966 (H. pycnanthi) were consistently the most aggressive (Table 3). Re-isolations from the lesions on the inoculated branches resulted in the recovery of inoculated fungi in some cases, but it was generally hampered by other faster growing fungi, especially those related to the Botryosphaeriaceae. The inoculated fungi were, however, never isolated associated with the control inoculations. 
Table 3 Average lesion lengths on bark (BLL) and cambium (CLL) caused by species of Ceratocystidaceae on cacao branches six weeks post inoculation. Values followed by the same letters are not significantly different based on TukeyHSD multiple range test.

\begin{tabular}{lllll}
\hline Fungal species & Isolate & CLL & BLL1 & BLL2 \\
\hline Th. cerberus & CMW 35021 & $50.17 \pm 22.85 \mathrm{~d}$ & $11.00 \pm 2.35 \mathrm{~cd}$ & $10.11 \pm 0.60 \mathrm{~cd}$ \\
& CMW35024 & $49.63 \pm 25.85 \mathrm{~d}$ & $11.00 \pm 1.41 \mathrm{~cd}$ & $9.78 \pm 0.97 \mathrm{~cd}$ \\
Th. ethacetica & CMW 35018 & $60.05 \pm 34.16 \mathrm{~cd}$ & $10.30 \pm 0.82 \mathrm{~d}$ & $10.22 \pm 0.83 \mathrm{~cd}$ \\
& CMW 35028 & $137.42 \pm 46.65 \mathrm{a}$ & $29.40 \pm 3.84 \mathrm{a}$ & $22.78 \pm 3.53 \mathrm{a}$ \\
H. chlamydoformis & CMW 36899 & $68.53 \pm 42.68 \mathrm{~cd}$ & $11.20 \pm 1.75 \mathrm{~cd}$ & $9.67 \pm 0.50 \mathrm{~cd}$ \\
& CMW 37104 & $58.42 \pm 22.15 \mathrm{~cd}$ & $13.00 \pm 4.70 \mathrm{c}$ & $11.00 \pm 1.41 \mathrm{~cd}$ \\
H. moniliformis & CMW 36922 & $58.74 \pm 32.58 \mathrm{~cd}$ & $10.70 \pm 1.34 \mathrm{~d}$ & $11.56 \pm 2.55 \mathrm{c}$ \\
H. pycnanthi & CMW 36895 & $49.53 \pm 20.87 \mathrm{~d}$ & $11.40 \pm 1.90 \mathrm{~cd}$ & $11.56 \pm 1.24 \mathrm{c}$ \\
& CMW 36917 & $75.67 \pm 34.09 \mathrm{c}$ & $11.40 \pm 1.17 \mathrm{~cd}$ & $10.67 \pm 0.71 \mathrm{~cd}$ \\
Control & CMW 36933 & $106.37 \pm 35.82 \mathrm{~b}$ & $15.90 \pm 2.18 \mathrm{~b}$ & $14.56 \pm 2.79 \mathrm{~b}$ \\
\hline
\end{tabular}

BBL1: Average bark lesion length for the first trial

BBL2: Average bark lesion length for the second trial 


\section{Fruit inoculations}

Most of the isolates inoculated onto mature cacao pods did not result in lesions. Only isolate CMW35028 (Th. ethacetica) caused rotting of inoculated pods (Figure 8). This fungus was consistently re-isolated from the margins of rotting fruit tissues.

\section{Discussion}

Results of this study to consider the diversity of the Ceratocystidaceae in cacao agroforests revealed that at least five species of these fungi are commonly found in this ecosystem in Cameroon. These include two species of Thielaviopsis (Th. cerberus and Th. ethacetica) and three species of Huntiella (H. chlamydoformis, $H$. moniliformis and $H$. pycnanthi), two of which are described as new. No species related to the genus Ceratocystis, well-known to accommodate destructive plant pathogens (Kile, 1993; Engelbrecht \& Harrington, 2005; Roux \& Winfield, 2009; van Wyk et al., 2013), including C. cacaofunesta that causes Ceratocystis wilt of cacao in Latin America (Engelbrecht et al., 2007) were found. Inoculation experiments revealed variable levels of pathogenicity among the recovered fungal species, with Th. ethacetica and $H$. pycnanthi sp. nov. emerging as potentially harmful cacao pathogens.

This study represents the first extensive consideration of species of Ceratocystidaceae on cacao in Cameroon, and more broadly in Africa. Previous reports of these fungi on cacao in that region include a study by Dade (1928), who first described the sexual state of Th. paradoxa on cacao pod husks in Ghana. Luc (1952), subsequently, described a "Theobromae" form of $H$. moniliformis on cacao roots in Madagascar. In the same publication, he also described a "Pycnanthi" form of the same fungus on Py. angolensis in Cameroon. The application of DNAbased tools has now made it possible to recognise a much richer diversity of the Ceratocystidaceae in Africa (Roux \& Wingfield, 2013) and elsewhere (de Beer et al., 2014 and 
references therein). However, there is little information regarding the impact of these fungi on cacao health in Africa, other than the inclusion of Th. paradoxa in the list of pathogenic fungi affecting cacao in Ghana (Anonymous, 1996).

Among the five fungal species recovered from cacao agroforests in this study, $H$. pycnanthi and Th. ethacetica showed substantial ability to cause lesions on cacao. These species both induced extensive discoloration and streaking of the vascular tissue on lignified cacao branches, similar to those developing from induced wounds on cacao stems in the field. In addition, Th. ethacetica was shown to cause fruit rot. Although $H$. moniliformis has previously been reported killing cacao trees in Costa Rica (Cristobal \& Hansen, 1962), the isolates used in inoculation tests in this study, as well as those representing $H$. chlamydoformis sp. nov., showed little pathogenicity on cacao. This is consistent with most prior knowledge of species in the genus Huntiella (previously treated in the Ceratocystis moniliformis complex), which are generally considered not to be pathogenic (e.g., Tarigan et al., 2010, Kamgan Nkuekam et al., 2012b).

Differences observed in the incidence of the Ceratocystidaceae between plantations could be linked to variation in prevailing agro-ecological conditions and management practices, including local average temperatures, humidity and shade levels in cacao fields. In this regard, relatively smaller lesions developed from cacao stem wounds in Bokito, which has a hotter and drier climate. These conditions, coupled with the limited shade on the farm, could have caused the wounds to dry rapidly, impeding further development and colonization by the fungi of the exposed wood tissues. H. pycnanthi was most commonly isolated from cacao tree wounds in Bokito. This was consistent with the fact that this fungus grows best at higher temperatures and in comparison to H. moniliformis that was more prevalent in Ngomedzap and Nkoemvone where cooler conditions prevail. 
Besides controlling the shade levels, other management practices that could influence the incidence of the Ceratocystidaceae in cacao fields include the identity of plants associated with cacao and the handling of pod husks after harvesting beans. For example, Th. cerberus, a fungus predominantly known from oil palm (Mbenoun et al., 2014a) was found only in Bokito, where this crop occurred alongside cacao. In contrast, most of the isolates of Th. ethacetica were collected from abandoned pod husk piles and only two isolates, from the same tree in Ngomedzap, came from cacao stem wounds. Interestingly, this fungus was not recovered at Nkoemvone where no pod husks occurred. This suggests that abandoned pod husk piles contribute to increase the inoculum of Th. ethacetica in cacao plantations, as was shown for Phytophthora spp. causing BPD (Bowers et al. 2001; Guest 2006). Moreover, we found that pod husk piles also provide suitable breeding conditions for nitidulid beetles that have been shown to transmit P. palmivora (Bult.) Bult. in cacao fields (Evans, 1973; Konam \& Guest, 2004). These insects are also well-known for their important role in the dispersal of tree pathogens related to the Ceratocystidaceae (Moller \& DeVay, 1968b; Hayslett et al., 2008; Heath et al., 2009).

Brachypeplus species were the most common nitidulid beetles found in association with species of Ceratocystidaceae in cacao agroforests, but other nitidulids such as Carpophilus species also occurred in these ecosystems. Brachypeplus species have previously been reported in association with members of the Ceratocystidaceae (Heath et al., 2009; Kamgan Nkuekam et al., 2012a). In particular, Heath et al. (2009) showed that B. depressus is one of the principal overland vectors of the wattle wilt pathogen, C. albifundus M.J. Wingf., de Beer \& M.J. Morris, in South Africa. In the present study, it emerged based on molecular data that the same Brachypeplus species visit both cacao stem wounds and abandoned pod husk piles in Cameroon. This highlights the possible role that these insects could play in the transmission of diseases between these substrates. 
Although evidence from this study suggests that some species of Ceratocystidaceae occurring in cacao agroforests in Cameroon have the potential to cause disease on cacao, these fungi are not recognized among the pathogens affecting this tree crop in the country. The real impact of the Ceratocystidaceae on cacao health and productivity, thus, needs to be further investigated. This could, for instance, involve assessing whether Th. ethacetica is associated with significant additional fruit losses other than that caused by P. megakarya. Species of Ceratocystidaceae could also be investigated in connection with tree mortality, especially as it occurs often following agri-silvicultural activities involving extensive tree wounding such as pruning, thinning and coppicing. In the interim, our study has shown that applying the well-known good management practices for pests and diseases of cacao (ICCO, 2009; Dropdata, 2012), including the maintenance of adequate levels of shade in plantation, an informed selection of intercropping systems and a proper handling of discarded pod husks can help reduce the incidence of the Ceratocystidaceae. This would reduce opportunities for new diseases caused by these fungi to emerge in cacao agrosystems.

\section{Acknowledgements}

We acknowledge the technical staff of the NKoemvone IRAD research station and Essomo Ngomba for their invaluable assistance during field studies. We are grateful to Ohono Emile, Essomba Cosmas and Mebenga René for allowing us to work on their farms. This study was funded by the NRF-DST Centre of Excellence in Tree Health Biotechnology (CTHB) of South Africa and the Department of Corporate International Relations of the University of Pretoria through a postgraduate "study abroad grant" awarded to the first author. 


\section{References}

Al Adawi AO, Deadman ML, Al Rawahi AK, Al Maqbali YM, Al Jahwari AA, Al Saadi BA, Al Amri IS, Wingfield MJ, 2006. Aetiology and causal agents of mango sudden decline disease in the Sultanate of Oman. European Journal of Plant Pathology 116, 247-254.

Anonymous, 1996. Checklists of crop plant diseases in Ghana [http://ghana.ipm-info.org/list diseases]. Last accessed 12 December 2014.

Barnes I, Roux J, Wingfield BD, Dudzinski MJ, Old KM, Wingfield MJ, 2003. Ceratocystis pirilliformis, a new species from Eucalyptus nitens in Australia. Mycologia 95, 865-871.

Bowers JH, Bailey BA, Hebbar PK, Sanago S, Lumsdem RD, 2001. The impact of plant diseases on world chocolate production. Plant Health Progress Online [http://www.plantmanagementnetwork.org/pub/php/review/cacao/] doi:10.1094/PHP-2001-0709-01-RV.Introduction.

Cristobal BD, Hansen AJ, 1962. Un hongo semjante a Ceratocystis moniliformis en cacao en Costa Rica. Turrialba $12,46-47$.

Dade HA, 1928. Ceratostomella paradoxa, the perfect stage of Thielaviopsis paradoxa (de Seynes) von Höhnel. Transactions of the British Mycological Society 13, 184-194, plates X-XII.

de Beer ZW, Duong TA, Barnes I, Wingfield BD, Wingfield MJ, 2014. Redefining Ceratocystis and allied genera. Studies in Mycology 79, 187-219.

Dropdata, 2012. Cocoa pests and diseases: Best managements practices [http://www.dropdata.org/cocoa/icm bkp.htm]. Last accessed 13 December 2014. 
Engelbrecht CJB, Harrington TC, 2005. Intersterility, morphology and taxonomy of Ceratocystis fimbriata on sweet potato, cacao and sycamore. Mycologia 97, 57-69.

Engelbrecht CJ, Harrington TC, Alfenas A, 2007. Ceratocystis wilt of cacao - A disease of increasing importance. Phytopathology 97, 1648-1649.

Evans HC, 1973. Invertebrate vectors of Phytophthora palmivora, causing black pod disease of cocoa in Ghana. Annals of Applied Biology 75, 331-345.

Evans HC, 2007. Cacao diseases — The trilogy revisited. Phytopathology 97, 1640-1643.

Garrett KA, Dendy SP, Frank EE, Rouse MN, Travers SE, 2006. Climate change effects on plant disease: genomes to ecosystems. Annual Review of Phytopathology 44, 489-509.

Gotsch N, 1997. Cocoa crop protection: an expert forecast on future progress, research priorities and policy with the help of the Delphi survey. Crop Protection 16, 227-233.

Guest D, 2006. Black pod: Diverse pathogens with a global impact on cocoa yield. Phytopathology 97, 1650-1653.

Hayslett M, Juzwik J, Moltzan B, 2008. Three Colopterus beetle species carry the Oak wilt fungus to fresh wounds on red Oak in Missouri. Plant Disease 92, 270-275.

Heath RN, Wingfield MJ, van Wyk M, Roux J, 2009. Insect associates of Ceratocystis albifundus and patterns of association in a native savanna ecosystem in South Africa. Environmental Entomology 38, 356-364.

ICCO, 2009. Overview of best practices in cocoa production [http://www.icco.org/about-us/international-cocoaagreements/cat_view/30-related-documents/32-consultative-board-on-the-world-cocoa-economy.html] Last accessed 13 December 2014. 
Kamgan Nkuekam G, Wingfield MJ, Mohammed C, Carnegie AJ, Pegg GS, Roux J, 2012a. Ceratocystis species, including two new species associated with nitidulid beetles, on eucalypts in Australia. Antonie van Leeuwenhoek 101, 217-241.

Kamgan Nkuekam G, Wingfield MJ, Roux J, 2012b. Ceratocystis species, including two new taxa, from Eucalyptus trees in South Africa. Australian Plant Patholology 42, 283-311.

Kile GA, 1993. Plant diseases caused by species of Ceratocystis sensu stricto and chalara. In: Wingfield MJ, Seifert KA, Webber JF, eds. Ceratocystis and Ophiostoma: Taxonomy, Ecology and Pathogenicity. St .Paul, Minnesota, USA: APS Press, 173-183.

Konam JK, Guest DI, 2004. Role of beetles (Coleoptera: Scolytidae and Nitidulidae) in the spread of Phytophthora palmivora pod rot of cocoa in Papua New Guinea. Australian Plant pathology 33, 55-59.

Luc M, 1952. Ophiostoma moniliforme (Hedgc.) H. et P. Syd. et ses diverses formes. Revue de Mycologie 17, 10-16.

Mbenoun M, Momo Zeutsa EH, Samuels G, Nsouga Amougou F, Nyasse S, 2008. Dieback due to Lasiodiplodia theobromae, a new constraint to cocoa production in Cameroon. Plant Pathology 57, 381.

Mbenoun M, de Beer ZW, Wingfield MJ, Wingfield BD, Roux J, 2014a. Reconsidering species boundaries in the Ceratocystis paradoxa complex, including a new species from oil palm and cacao in Cameroon. Mycologia 106, $757-784$.

Mbenoun M, Wingfield MJ, Begoude Boyoguneno AD, Wingfield BD, Roux J, 2014b. Molecular phylogenetic analyses reveal three new Ceratocystis species and provide evidence for geographic differentiation of the genus in Africa. Mycological Progress 13, 219-240. 
Mbile P, Ngaunkam P, Besingi M, Nfoumou C, Degrande A, Tsobeng A, Sado T, Menimo T, 2009. Farmer management of cocoa agroforests in Cameroon: impacts of decision scenarios on structure and biodiversity of indigenous tree species. Biodiversity 10, 12-19.

Mfegue CV, 2012. Origine et mécanismes de dispersion des populations de Phytophthora megakarya, pathogène du cacaoyer au Cameroun. Montpellier, France : Centre International d'Etudes Supérieures en Sciences Agronomiques - Montpellier SupAgro, Ph.D. thesis.

Moller WJ, De Vay JE, 1968a. Carrot as species-selective isolation medium for Ceratocystis fimbriata.

Phytopathology 58, 123-126.

Moller WJ, DeVay JE, 1968b. Insect transmission of Ceratocystis fimbriata in deciduous fruit orchards.

Phytopathology 58, 1499-1508.

Morgan-Jones G, Booth C, Pirozynski A, 1967.CMI descriptions of pathogenic fungi and bacteria, Set No 15. Kew, Surrey, England: Commonwealth Mycological Institute.

Ploetz RC, 2007. Cacao diseases: important threats to chocolate production worldwide. Phytopathology 97, 1634139.

Rayner RW, 1970. A mycological colour chart. Kew, Surrey UK: Commonwealth Mycological Institute and British Mycological Society.

Rice RA, Greenberg R, 2000. Cacao cultivation and the conservation of biological diversity. AMBIO 29, 167-173.

Roux J, Wingfield MJ, 2009. Ceratocystis species: emerging pathogens of non-native plantation Eucalyptus and Acacia species. Southern Forests 71, 115-120. 
Roux J, Wingfield MJ, 2013. Ceratocystis species on the African continent, with particular reference to $C$. albifundus, and African species in the C. fimbriata sensu lato species complex. In: Seifert KA, de Beer ZW, Wingfield MJ, eds. The ophiostomatoid fungi: expanding frontiers. Utrecht, the Netherlands: CBS biodiversity series, vol. 12, 131-138.

Schroth G, Krauss U, Gasparotto L, Duarte Aguilar JA, Vohland K, 2000. Pests and diseases in agroforestry systems of the humid tropics. Agroforestry Systems 50, 199-241.

Seifert KA, de Beer ZW, Wingfield MJ, eds, 2013. The ophiostomatoid fungi: expanding frontiers. Utrecht, The Netherlands: CBS Biodiversity Series, vol. 12.

Simon C, Frati F, Beckenbach A, Crespi B, Liu H, Flook P, 1994. Evolution, weighting, and phylogenetic utility of mitochondrial gene sequences and a compilation of conserved polymerase chain reaction primers. Annals of the Entomological Society of America 87, 651-701.

Sonwa DJ, Weise S, Adesina A, Nkongmeneck AB, Tchatat M, Ndoye O, 2005. Production constraints on cocoa agroforestry systems in West and Central Africa: The need for integrated pest management and multi-institutional approaches. The Forestry Chronicle 81, 345-349.

Swofford DL, 2002. Phylogenetic analysis using parsimony (*and other methods), Versoin 4. Sunderland, Massachusetts, USA: Sinauer Associates.

Tamura K, Peterson D, Peterson N, Stecher G, Nei M, Kumar S, 2011 MEGA5: molecular evolutionary genetics analysis using maximum likelihood, evolutionary distance, and maximum parsimony methods. Molecular Biology and Evolution 28, 2731-2739.

Tarigan M, van Wyk M, Roux J, Tjahjono B, Wingfield MJ, 2010. Three new Ceratocystis spp. in the Ceratocystis moniliformis complex from wounds on Acacia mangium and A. crassicarpa. Mycoscience 51, 53-67. 
van Wyk M, Wingfield BD, Wingfield MJ, 2013. Ceratocystis species in the Ceratocystis fimbriata complex. In: Seifert KA, de Beer ZW, Wingfield MJ, eds. The ophiostomatoid fungi: expanding frontiers. Utrecht, the Netherlands: CBS biodiversity series, vol. 12, 65-73.

Wingfield MJ, Seifert KA, Webber JF, eds, 1993. Ceratocystis and Ophiostoma: Taxonomy, Ecology and Pathogenicity. St. Paul, Minnesota, USA: APS Press.

Wingfield MJ, Roux J, Wingfield BD, Slipppers B, 2013. Ceratocystis and Ophiostoma: international spread, new associations and plant health. In: Seifert KA, de Beer ZW, Wingfield MJ, eds. The Ophiostomatoid fungi: expanding frontiers. Utrecht, the Netherlands: CBS Biodiversity Series, vol. 12, 191-200. 


\section{Supplementary materials}

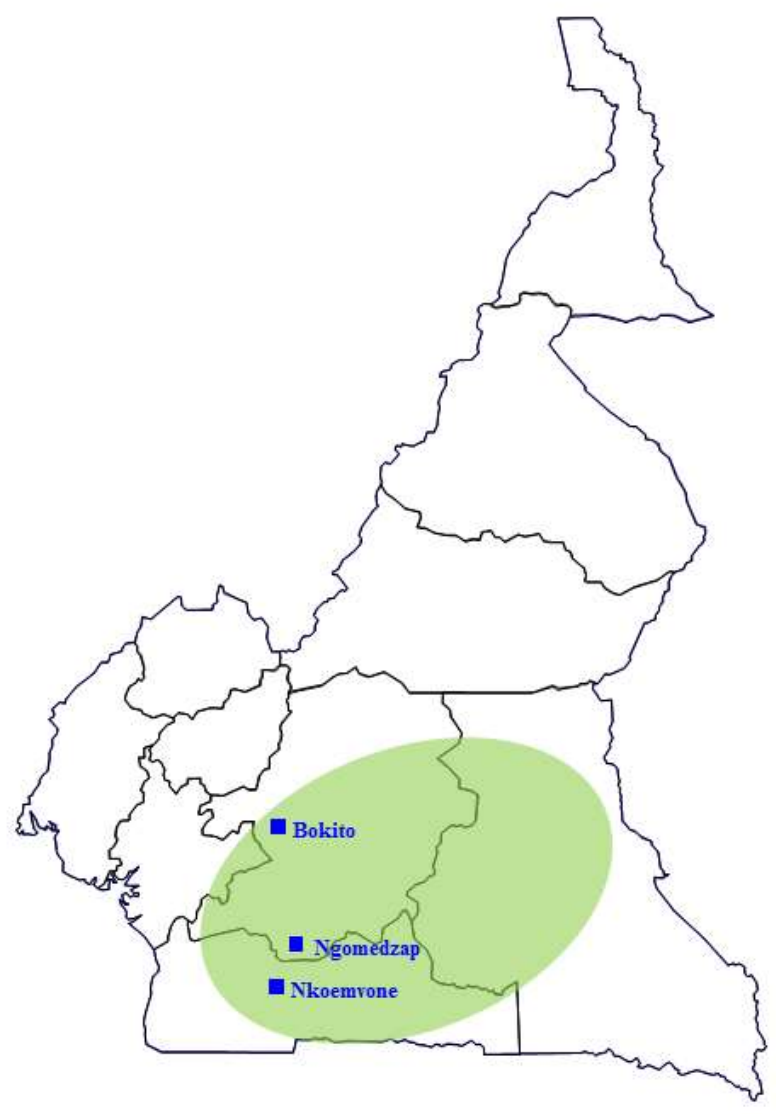

Figure S1 Map of Cameroon showing the Centre-South cacao growing region (shaded) and the sites involved in this study. The map was adapted from Efombagn et al. (2008) 

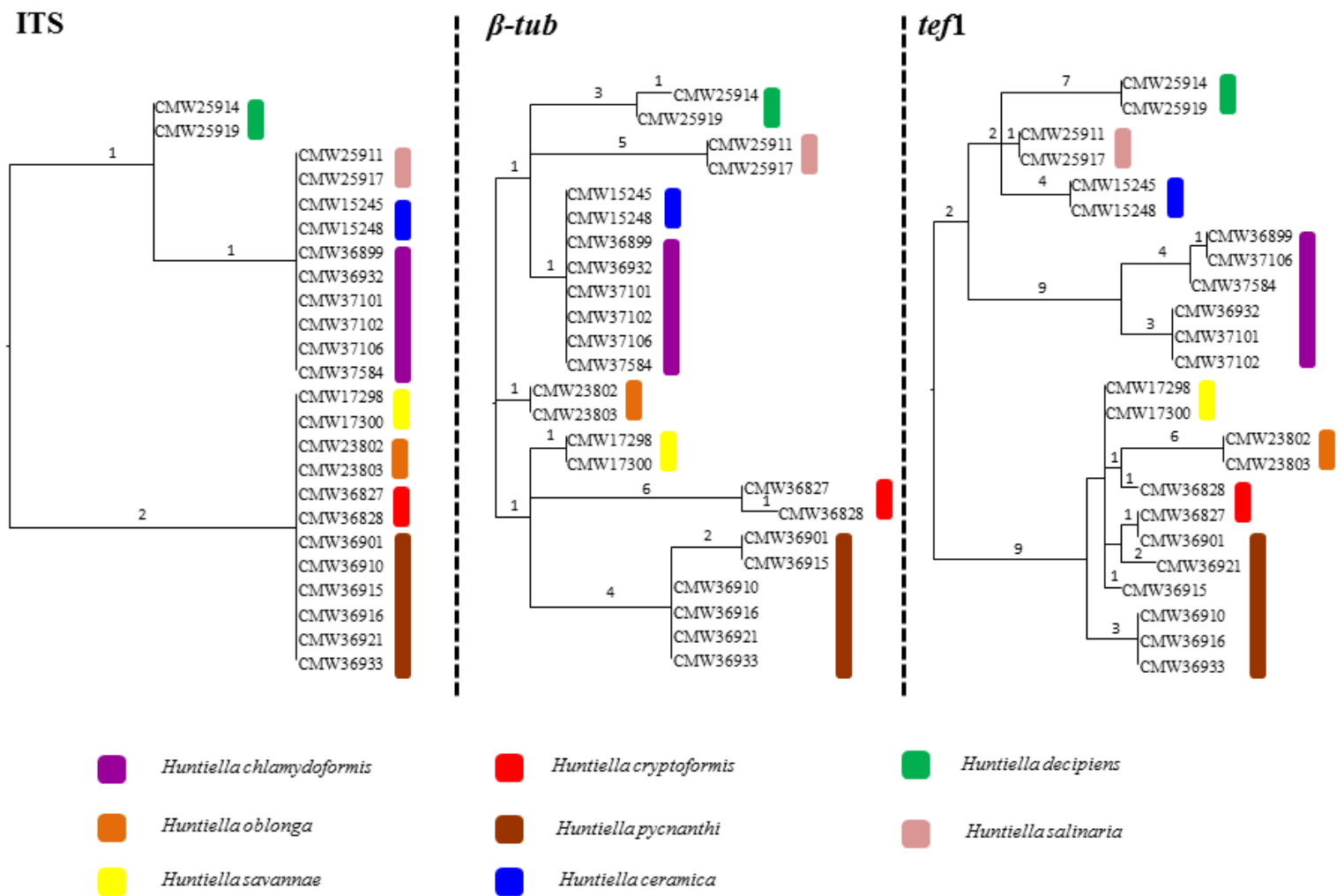

Figure S2 Phylogenetic relationships between the new Huntiella species discovered in cacao agroforests in Cameroon and their closest known relatives based on single gene loci. The number of corresponding nucleotide substitutions is indicated above tree branches. 


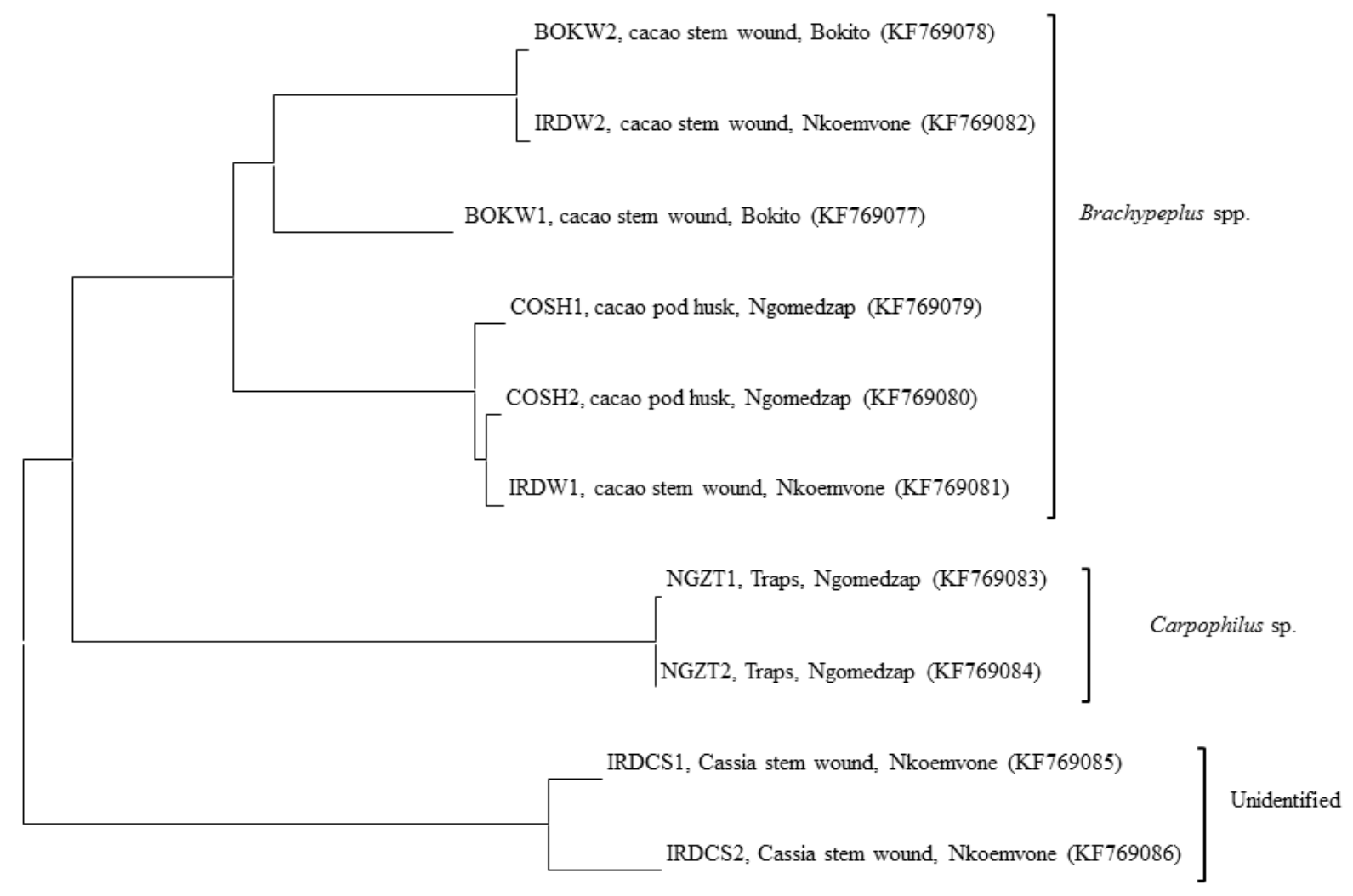

Figure S3. Neighbour joining phylogenetic tree of nitidulid beetles found in cacao agroforests in Cameroon based on MT-CO1 gene sequences. GenBank accession numbers of sequences are provided in parentheses.

\section{TreeBase information}

http://purl.org/phylo/treebase/phylows/study/TB2:S16363?x-access-code=55dd6cfb410c327cb75d39b1c1969b11\&format=html http://purl.org/phylo/treebase/phylows/study/TB2:S16363 